The Labore Journal of Economics

Special Edition

\title{
Institutional Machinery for Managing the Pakistan Economy
}

\section{Pervez Tahir ${ }^{*}$}

\section{Introduction}

In the heyday of the five year plans in Pakistan, the common expressions for the officials dealing with the economy and their institutional affiliations were "planners" and "planning machinery." The fiscal crisis of the state and the consequent installation of regimes of stabilization, structural adjustment and reform gave birth to usages such as "economic manager," "economic management" and "economic team." It has also marked a shift from the long and medium-term to the near-and short-term. This paper, however, adheres to the broader view of the management of the economy and its institutions taken by Anmad and Amjad in the eighties. According to them, "National economic management is a new but growing science. The developing world's experience of the recent decades underlines the fact that economic and social progress is an induced process. Governments are not only called upon to initiate the development process but are also required to influence its composition, pace, tone, and direction through an appropriate policy-mix. A consistent framework encompassing various policies within the bounds of an overall national strategy needs to be worked out by the national policy-makers." These authors also pointed out that there was a gap between the increasing requirements of management and the capabilities of individuals and institutions. "Economic management has thus become a critical area for study as well as introspection."

We outline here the institutional machinery for managing the Pakistan economy to show that it is alive though not always kicking. While its resilience is commendable, the capability to deliver desired outcomes calls for reflection.

\footnotetext{
* Chief Economist, Government of Pakistan, Planning Commission, Islamabad. The paper has been written in personal capacity and the usual disclaimers strictly apply.

${ }^{1}$ Viqar Ahmed and Rashid Amjad, The Management of Pakistan's Economy. Karachi: Oxford University Press, 1984, P.V.
} 


\section{National Economic Council}

The apex institution for managing the economy of Pakistan has been provided in the Constitution of Pakistan Article 156(2) of the Constitution states: 'The National Economic Council shall review the overall economic condition of the country and shall, for advising the Federal Government and the Provincial Governments, formulate plans in respect of financial, commercial, social and economic policies; and in formulating such plans, it shall be guided by the Principles of Policy set out in Chapter 2 of Part II. Headed by the chief executive of the country, the National Economic Council (NEC) has as its members the provincial chief executives, cabinet ministers concerned with economic and social development and the Deputy Chairman of the Planning Commission (Annex I). A working definition of Macroeconomic Framework is that it is a summary statement of a country's development strategy and economic policies, based on past assessment and future prospects and expressed in physical as well as financial terms. In this sense, the mandate of the NEC covers all the key elements of the macroeconomic framework. Read with the Principles of Policy laid down by the Constitution (Annex II) which guide policy formulation, the mandate becomes a comprehensive development framework.

Vision statements, long term perspectives, five year plans, annual plans and the Public Sector Development Programs (PSDP) require the approval of the NEC. Pakistan 2010 was the first ever vision statement approved by the NEC in 1998, while Vision 2030 will be submitted to it soon. Similarly, the first perspective plan was endorsed in the mid-sixties for 1965-85 and the last perspective plan, called the Ten Year Perspective Plan 2001-1, was approved on June 7, 2001. The practice of approving three-year rolling plans also started within the framework of this Perspective Plan. Preparation and approval of five year plans started in 1957, which came to a halt with the abortive Fourth Five Year Plan 1970-75. It was resumed with the Fifth Five Year Plan 1978-83 and continued until 1998. The draft Ninth Five Year Plan 1998-2003 was prepared but not placed before the NEC. The exercise has been re-started after the recent authorization by the NEC for the preparation of the Medium Term Development Framework (MTDF) 2005-10.

Annual plans were introduced in 1968 and their preparation and approval has continued without interruption. Annual development programs, these days called the PSDP, go back to the start of planning in the fifties. These related to the public sector, while annual plans take an overall view of the economy, public as well as private investment. 
Ever since its inception, the NEC has been meeting regularly before the budget towards the end of May or early June. Since 2004, it has decided to meet during the fiscal year also to consider mid-year economic reviews and to monitor the progress of major projects and the utilization of the PSDP. In regard to projects and programs, the NEC has delegated its authority to its Executive Committee, the ECNEC.

\section{The Cabinet and the Parliament}

Though an apex body, the plans approved by the NEC are in the nature of an advice to the constituents of the Federation. In the light of this advice, the federal government goes to the cabinet for the clearance of the federal budget, which incorporates proposals regarding development and non-development expenditure, and the tax and non-tax resources to be mobilized for financing, besides the debts to be incurred and serviced. The final approval of the federal budget lies with the National Assembly. A similar process is followed in the provinces. While the Senate does not approve money bills, it debates the budgetary proposals and sends its recommendations to the National Assembly, which is the constitutional forum for the approval of the budget.

The federal budget, prepared by the Ministry of Finance in the light of the directions provided by the NEC, constitutes the official statement on fiscal policy. It is tabled in the National Assembly of Pakistan and transmitted to the Senate of Pakistan in terms of Article 80(1) of the Constitution of the Islamic Republic of Pakistan which requires that an Annual Budget Statement of estimated receipts and expenditure for that year be laid before the National Assembly and Article 73(1) mandating that a copy be transmitted to the Senate of Pakistan. Again, as per Article 80 (2), the Annual Budget Statement shows separately: (a) the sums required to meet expenditure described by the Constitution as expenditure charged upon the Federal Consolidated Fund; and (b) the sums required to meet other expenditure proposed to be made from the Federal Consolidated Fund.

In addition to the Federal Budget, the Cabinet approves other policies which are not necessarily placed before the Parliament. Among economic policies, these include trade policy prepared by the Ministry of Commerce, privatization policy, investment policy, labor policy, etc. In the same genre lie various sectoral policies prepared by the concerned line ministries, such as industrial policy, agricultural policy, water policy, transport policy, housing policy, health policy, education policy, national conservation strategy, etc. 


\section{Economic Coordination Committee (ECC) of the Cabinet}

The ECC is not only the most frequented but also the most frequently convened Cabinet Committee (Annex III). Meeting every fortnight, it is the main coordination point for economic policies, especially fiscal, monetary, trade and tariff policies. It also adjusts these policies to the events requiring urgent corrective action. The forum has been used for the approval of some important policies as well. These include power policy and on-lending policy for foreign credits. As the watchdog for prices and inflation, the ECC takes remedial actions whenever and wherever necessary.

\section{Annual Plan Coordination Committee (APCC)}

Of crucial significance is the observance of the discipline of the plan and its scheme of proportions and balances. The plan can be altered when circumstances so warrant but not without the concurrence of the NEC. After the five year plan is approved and published, its successive annual plans are prepared by the Planning Commission, deliberated upon at the Annual Plan Coordination Committee (APCC) and finally approved by the NEC when it meets before the federal budget. The APCC is chaired by the Deputy Chairman of the Planning Commission and is composed of provincial planning and finance ministers and the concerned federal and provincial secretaries (Annex IV). An annual plan document is published along with the budget documents.

The APCC also finalizes the PSDP as part of the Annual Plan. The PSDP is an annual document which lists all the public sector projects/ programs with specific allocations made for each one of them in that particular financial year. It is the operational side of the five year and annual plans. In other words, it is that part of the country's annual budget which deals with development expenditure, indicating the total cost of a project, foreign exchange component of the total cost, expenditure incurred upto the end of the last financial year, PSDP allocation for the current financial year together with its foreign aid component. Proposals for the consideration of the APCC come from the Priority Committee.

\section{Priorities Committee}

The PSDP formulation is a crucial component of the planning process. It embraces projects which have been approved by the sanctioning machinery of the Government after due scrutiny-technical, financial and organizational. But the PSDP procedure differs from the project approval 
procedure. Due to scarcity of resources, projects compete for funds available for development. An essential part of the procedure, therefore, is a shift from the examination of a project in isolation to the selection of projects out of a large portfolio of approved projects. The procedure is laid down in detail in a PSDP call letter sent out in October/November, in tandem with the budget call letter by the Finance Division, to all Government Ministries/Divisions, Provincial Governments. It sets up a time-schedule along with guidelines on the preparation of the PSDP and selection of projects.

Proposals received from the executing agencies and the preliminary assessment of the Planning Commission are processed at the Priorities Committee chaired by the Ministry of Finance, which are subsequently submitted to the APCC. Annex V gives its composition. After the PSDP proposed by the Planning Commission is approved by the NEC, it is incorporated into the annual budget. In the past, the Priority Committee was chaired by the Planning Commission. The Ministry of Finance has an important role in the determination of the size of the PSDP because of the responsibility it bears for the mobilization of resources. Whether this role justifies leaving the priority assignment to the Finance Division is often a matter of lively debate.

\section{Appraisal and Approval of Schemes}

A scheme is a proposal for a project or program. Plans frequently form the basis of identifying new schemes. Under a systematic planning procedure, planners only determine general guidelines for the fulfillment of overall development goals. These goals are further translated into specific sectoral objectives, alongwith overall resource allocation between them. Sectoral planning needs more specific information about the resources and constraints of the sectors concerned. After the collection of this information, disaggregated projects and programs are devised which are individually appraised in the light of guidelines and macro-economic parameters provided by the NEC/APCC.

Projects and programs to be included in the Public Sector Development Program require approval of competent fora. These are discussed in the following paragraphs.

Executive Committee of National Economic Council (ECNEC): This is the highest body for the approval of schemes. Projects and programs costing Rs.500 million and above are approved by the ECNEC. It is headed by the Prime Minister/Finance Minister and has representation from all 
development and economic Ministries and Provinces at the Minister leve1 (Annex VI).

Central Development Working Party (CDWP): Development projects costing between Rs. 40 million and Rs. 500 million prepared by the Federal Ministries, Provincial Governments, Autonomous Organizations, etc., are scrutinized for the purpose of approval by the Central Development Working Party (CDWP) which is headed by the Deputy Chairman, Planning Commission and includes as its members the Secretaries of the Federal Ministries concerned with development and the heads of the Planning Departments of the Provincial Governments (Annex VII). Schemes with foreign funding of 25 percent and above have also to come to CDWP. The Concept Clearance Committee (CCC), which has the same composition and meets concurrently with the CDWP, allows negotiations with foreign donors before the project is ready for approval. But a project contract is only signed once it is approved by the CDWP for ensuring the availability of local/counterpart funds. The schemes cleared by the CDWP costing more than Rs.500 million are submitted to the ECNEC for final approval.

Departmental Development Working Party (DDWP): This is the forum for approving development projects/programs for Federal Ministries/Divisions/Departments costing upto Rs.40 million. It is headed by the respective Secretary/Head of Department and includes representatives of the Finance Division and Panning Commission (Annex VII).

Provincial Development Working Party (PDWP): Each Province has a Provincial Development Working Party which is headed by the Chairman, Development Board/Additional Chief Secretary (Development) and includes Secretaries of the Provincial Departments concerned with development (Annex VII). The PDWP scrutinizes and approves schemes costing upto Rs.200 million, with foreign exchange cost of less than 25 per cent. Any scheme involving 100 per cent self-finance can be approved by the PDWP for upto Rs.1000 million.

The Planning Commission is responsible for the development of appropriate cost and physical standards for the effective technical and economic appraisal of the projects. Before the projects are sanctioned by the CDWP/ECNEC, their technical appraisal is carried out by the concerned technical sections of the Planning Commission. This includes the engineering, commercial, governance, environmental and managerial aspects. Economic Appraisal Section analyzes the projects from economic, financial and social viewpoints. 


\section{Monitoring and Evaluation}

The present method for planning, processing and reporting on development projects is based on five proformae. Two of these deal with submission of project proposals (PC-I and PC-II) and are required for the appraisal and approval of projects. Another one is concerned with the progress of ongoing projects (PC-III) and the remaining two (PC-IV and PCV) are to be filled in after completion of a project. As is obvious, PC-I11 relates to monitoring. All project directors are required to submit quarterly progress report on a prescribed proforma. The most important indicators are the achievement status of financial and physical targets and the identification of bottlenecks. Inter-agency teams coordinated by the Projects Wing of the Planning Commission also undertake periodic site visits.

The purpose of monitoring is to assist in effective implementation while evaluation provides lessons for the future. Evaluation is of two types: project evaluation and plan evaluation. Project evaluation is carried out after completion. It focuses more on output indicators than the input indicators used for monitoring. For the purpose of evaluation, PC-IV is required to be submitted when the project is adjuded complete and PC-V is to be submitted annually for five years by the agency responsible for operation and maintenance. Plan evaluation is concerned with the evaluation of a five year plan against its physical and financial targets, policy thrusts and strategic shifts. Typically the Planning Commission undertakes a mid-plan evaluation, preliminary evaluation and final evaluation.

Monitoring of development projects is necessary to check cost and time over-runs in the implementation of projects. Delay in completion of projects causes irreparable loss to the economy. The examples of delayed projects are Ghazi Brotha Hydro Power Transmission Project, IslamabadPeshawar Motorway (M-1), Neelum Jhelum Complex and Thar Coal Power Project. Keeping this in view, the NEC decided on 29 May, 2003 that monitoring of PSDP projects would be a top priority. The approach was changed from 2003-04 to undertake field monitoring of approved development projects costing Rs. 40 million and above. Projects costing less than Rs. 40 million would be monitored by sponsoring ministries. The findings were communicated to the executing agencies and placed on the external web for public review. Presentations were made to ECNEC/NEC also. In fact, the ECNEC has been meeting quarterly and the NEC twice a year to properly focus on monitoring.

This system involved all officers of the Planning Commission in field monitoring, and not just the Project Wing. While it over-extended the staff 
capability, the involvement of the concerned Ministries was not as much as to build the desired ownership. In order to enable the Ministries to play a more proactive role in supervising their development portfolio, it has recently been decided that in future, the ministries/divisions would ensure regular monitoring of all their projects included in the PSDP and send a monthly report for each project to the Planning and Development Division. In case of foreign aided projects, a copy of the report would also be provided to the Economic Affairs Division. The Principal Accounting Officers, i.e. the Secretaries are required to hold monthly monitoring meetings personally so as to ensure effective implementation of the projects under their jurisdiction. The Planning and Development Division will, however, continue to undertake monitoring of projects on a selective basis. The Projects Wing has been strengthened by the creation of an Evaluation \& MIS Section. Also, development of an electronic link to have a fast and regular exchange of information with the project authorities, Ministries, EAD, Finance Division \& AGPR \& Provincial Governments is planned.

The Prime Minister has also constituted a high level Project Monitoring Committee under the Advisor to the Prime Minister on Finance and Revenue, which will communicate the progress of projects costing Rs. 500 million and above to the Prime Minister every month. The Projects Wing will be the focal point of all the monitoring and evaluation activities of the Public Sector Development Program. Performance indicators are being developed to access timely and efficient implementation of projects. The outcome of the monitoring exercise will be presented on a quarterly basis to ECNEC and biannually to NEC for seeking guidance and policy decisions. The Project Wing will ensure that all the decisions and directives of NEC/ECNEC are implemented. Each executing ministry will establish a planning and monitoring cell as per ECNEC decision to ensure effective monitoring of development projects. Strengthening the monitoring and evaluation sections of provincial P\&D Departments/Board to ensure effective implementation of their development projects/programs, has become a priority. Linkages with District Monitoring Development Committees under the Local Government Ordinance will be ensured. Finally, better coordination with Pakistan Planning and Management Institute (PPMI) for training of Project Directors in the fields of Project Management, Monitoring and Evaluation is yielding good results.

The PPMI has initiated a training program for the project directors. The main objectives of the training is to prepare professionals for the effective implementation of the development projects. Efforts are being made to train all Project Directors of Projects costing Rs. 100 million and above included in 
the PSDP 2004-05. Toward this end the ECNEC has made PPMI's training course mandatory for officers to be appointed as Project Directors.

\section{Monetary and Fiscal Policies Coordination Board}

Under its law, the State Bank of Pakistan is responsible for regulating the monetary and credit system of the country. The general superintendence and direction of the affairs and business of the State Bank vests in the Central Board of Directors. The Central Board consists of the Governor, Secretary, Finance Division, Government of Pakistan; and seven Directors, including one Director from each Province nominated by the Federal Government while also ensuring representation to the agriculture, banking and industrial sectors. The Governor is the Chairman of the Central Board and all decisions are taken by the majority of members present and voting with the provision that in the event of equality of votes, the Governor may exercise a casting vote. The Board

- formulates, evaluates and monitors monetary and credit policy

- determines the expansion of liquidity, consistent with targets of growth and inflation ensuring that the monetary and credit policy is consistent with macroeconomic policy objectives

- determines and enforces the limit of credit by the Bank to the Federal and Provincial Governments

- acts as a policy adviser to the Federal Government

- submits a quarterly report on the sate of the economy to the Parliament.

As the conduct of monetary and exchange rate policies is the domain of the State Bank of Pakistan, a separate institution has been provided in the State Bank Act to ensure overall coordination and harmonization of economic policies. Called Monetary and Fiscal Policies Coordination Board, it meets before the announcement of the budget to avoid policy anomolies and to enable the preparation of a consistent macroeconomic framework. Its functions and composition are given at Annex VIII.

\section{Other Cabinet Committees}

Other Cabinet Committees relate to Social Sector Coordination, Investment, Privatization, Regulatory Bodies and Agriculture. Their role is 
formulation of policies for approval by the relevant fora, inter-ministerial coordination and monitoring. Annex IX-XIII give their functions and composition.

\section{Other Decision Fora}

Pakistan Environmental Protection Council provides policy guidelines for environment aad sustainable development. Private Power and Infrastructure Board clears proposals for investment in the power sector by the private sector.

\section{A Summing Up}

The review of the institutional machinery presented here indicates its elaborate nature. It has matured overtime by allowing increasing decentralization of sanctioning powers, greater emphasis on policy planning and expanding role for monitoring to improve implementation. The machinery has, over time, adjusted well to the changing role of the state as a catalyst in the expansion of opportunities. There are problems of capacity, difficulties in the way of creating a culture of monitoring, a distaste for evaluation and absence of post-evaluation. While the quality of macro economic policy-making has improved, the sector policy work leaves much to be desired. The reason for the latter is the persistence of the project mindset in sectoral planning. An example here is the inability to work out innovative public-private partnerships. In the phase of second-generation reform, analytical capacity for microeconomic policy will have to improve.

There has been an essential continuity in the process of economic planning since the launch of the First Five Year Plan in the late 1950s. The continuity was maintained even during the interregnum of the 1970s when medium-term planning was abandoned. This continuity has been possible because the cutting edge of planning has been the Public Sector Development Program (PSDP), which is prepared as part of the budget annually, and under which the size and composition of public investment expenditures are determined. Both five year plans and annual plans, by contrast, are documents of an advisory nature. To the extent that they reflect the economic philosophy of the government, however, they provide a reference point for policy decisions.

In recent years this cutting edge has been blunted by the rapidly shrinking fiscal space. The PSDP has experienced a sharp fall from 9.5 per cent of GDP in the first year (1978-79) of the Fifth Plan period to under 3.0 per cent in recent years. Not only has the allocation made in the budgets been smaller, relatively as well as in real terms, the releases lag behind 
allocations and the utilization lags behind releases. A number of steps have been taken recently to improve utilization. These include, on the side of the Planning Commission, (1) the preparation of Cash/Work Plans by the Ministries/Divisions (2) approval of Cash/Work Plans by the Planning and Development Division (3) quarterly review of PSDP to monitor the releases and expenditure of each project included in PSDP (4) adjustments in allocations on the basis of releases/expenditure incurred by various projects during each quarter and revision of Cash/Work Plans for projects for which re-allocation is made. On the side of the Finance Division, the steps include (1) release of funds on the basis of Cash/Work Plans approved by the Planning and Development Division and (2) to make releases to projects in line with quarterly adjustments made by the Planning and Development Division.

In the sixties when Pakistan started receiving large doses of foreign aid, it turned out that the country did not have a sufficient number of good projects for timely absorption of aid. The system of project approval, which was also strengthened in the sixties as part of the process of putting in place an elaborate planning framework, responded by building over time a large project portfolio. As the deceleration of net aid inflows set in and fiscal deficits assumed unmanageable proportions, the resources available to accommodate new approved projects were constrained. A re-defined role of the government to encourage private initiatives had its own role in reducing the scope of PSDP.

Approval of a project does not mean automatic inclusion in PSDP, but it does create pressure for inclusion. The common practice is to press for token allocation in the hope that inclusion will enable larger allocations subsequently. This leads to the problem of a huge throw forward of ongoing projects, in addition to the pressures generated by a large portfolio of the approved projects. Huge resources are preempted by the on-going commitments. The accommodation of the throw forward leaves very little for new initiatives. In general, new initiatives have not been included as a result of spring-cleaning exercises. The allocations for on-going projects are adjusted to create space for new initiatives, and actual releases are slowed down further to respond to the political pressures for new initiatives. Today's new initiatives are tomorrow's on-going burden. The rapid political turnover left its own baggage. To speed up new initiatives, the escape routes of anticipatory approvals, special programs, dispersal of approving authority in the name of decentralization and autonomy have been adopted. The inevitable outcome is a thinly spread resources envelope.

Donors' response to this maze of project proliferation has been to define a set of core projects and priority programs, which are protected by a 
variety of conditionalities. This core periperalizes national priorities. Concept clearance, essentially an authorization to negotiate with donors, is another dimension of the pressures to approve. Projects are sometimes concept cleared even when it is the beginning of an idea whose time may not have come.

The distinction between development and non-development budgets makes it difficult to match development with resource availability. It also works against effective service delivery, particularly in social sectors. A medium term budgetary framework exercise has been started to overcome this disconnect.

Table-1: Plan Discipline and Growth Rate

\begin{tabular}{lcl}
\hline \multicolumn{1}{c}{ Period } & $\begin{array}{c}\text { GDP Growth per } \\
\text { annum (\%) }\end{array}$ & \multicolumn{1}{c}{ Plan Discipline } \\
\hline 1950-55 & 3.2 & Non-Plan Period \\
1st Plan (1955-60 & 3.1 & Low \\
2nd Plan (1960-65) & 6.8 & Highest \\
3rd Plan 1965-70) & 6.7 & Highest \\
1970-78 & 4.4 & Non-Plan Period \\
5th Plan (1978-83) & 6.7 & High \\
6 $^{\text {th Plan (1983-88) }}$ & 6.3 & High \\
7th Plan (1988-93) & 4.8 & Medium \\
8th Plan (1993-98) & 4.3 & Low \\
1998-2005 & 4.5 & Non-Plan Period \\
MTDF 2005-10 & $7.4^{*}$ & To start on 1st July, 2005 \\
\hline
\end{tabular}

* Target

A simple test of the extent to which the institutional machinery has been effective would be the growth rate achieved. Table 1 categorizes the various periods of management in the history of the country by the level of discipline of medium-term planning. It will be seen that the highest growth rates are associated with the highest level of plan discipline. Thus the institutional machinery, when allowed to work consistently over the medium term, does deliver a respectable level of wealth creation. Whether this wealth in produced and distributed equitably is an area where this institutional machinery will have to undergo a profound set of reforms. 


\section{Annexure-I}

\section{National Economic Council (NEC)}

\section{Composition}

\section{Federation}

1. The Prime Minister Chairman

2. Minister for Commerce Member

3. Minister for Communications “

4. Minister for Education “

5. Minister for Environment “

6. Minister for Food, Agriculture \& Livestock “

7. Minister for Health “

8. Minister for Housing \& Works “

9. Minister for Industries \& Production “

10. Minister for Information and Broadcasting “

11. Minister for Information Technology \&. Telecommunications “

12. Minister for Kashmir Affairs \& Northern Areas “

13. Minister for Labor, Manpower and Overseas Pakistanis “

14. Minister for Local Govt. and Rural Development “

15. Minister for Petroleum and Natural Resources “

16. Minister for Planning \& Development(when appointed) “

17. Minister for Population Welfare “

18. Minister for Ports and Shipping “

19. Minister for Privatization and Investment “ 
20. Minister for Railways

21. Minister for State and Frontier Regions

22. Minister for Science and Technology

23. Minister for Social Welfare \& Special Education

24. Minister for Water \& Power

25. Adviser to the Prime Minister on Finance

26. Deputy Chairman, Planning Commission

\section{Provinces}

(1) Chief Ministers

(2) Provincial Finance Ministers”

(3) Provincial Planning Ministers

(4) Chairman, Planning and Development Board/

Additional Chief Secretaries (Development) of the Provinces.
Member

Note:

a) The Prime Minister, Finance Minister, Planning Minister, and Additional Chief Secretary(development) of the Azad Govt. of the State of Jammu \& Kashmir will be specially invited in the meetings of the NEC.

b) Governor NWFP will specially be invited in the meetings of the NEC to represent FATA.

c) Secretaries of the Federal Ministries concerned, Governor State Bank of Pakistan, Chairman WAPDA and Chairman, National Highway Authority will be invited as special invitees in the NEC Meetings.

d) The council may appoint such committees or bodies of experts, officials and technocrats and associate with its deliberations and meetings as may be necessary to assist the Council in the performance of its functions. 


\section{Annexure-II}

\section{Principles of Policy}

\section{[Chapter 2 of Part II of the Constitution]}

29. (2) In so far as the observance of any particular Principle of Policy may be dependent upon resources being available for the purpose, the Principle shall be regarded as being subject to the availability of resources.

30. (2) The validity of an action or of a law shall not be called in question on the ground that it is not in accordance with the Principles of Policy, and no action shall lie against the State, any organ or authority of the State or any person on such ground.

32. The State shall encourage local Government institutions composed of elected representatives of the areas concerned and in such institutions special representation will be given to peasants, workers and women.

34. Steps shall be taken to ensure full participation of women in all spheres of national life.

35. The State shall protect the marriage, the family, the mother and the child.

37. The State shall-

(a) promote, with special care, the educational and economic interests of backward classes or areas;

(b) remove illiteracy and provide free and compulsory secondary education within minimum possible period;

(c) make technical and professional education generally available and higher education equally accessible to all on the basis of merit;

(d) ensure inexpensive and expeditious justice; 
(e) make provision for securing just and humane conditions of work, ensuring that children and women are not employed in vocations unsuited to their age or sex, and for maternity benefits for women in employment;

(f) enable the people of different areas, through education, training, agricultural and industrial development and other methods, to participate fully in all forms of national activities, including employment in the service of Pakistan.

(g) Decentralize the Government administration so as to facilitate expeditious disposal of its business to meet the convenience and requirements of the public.

38. The State shall-

(a) Secure the well-being of the people, irrespective of sex, caste, creed or race, by raising their standard of living, by preventing the concentration of wealth and means of production and distribution in the hands of a few to the detriment of general interest and by ensuring equitable adjustment of rights between employers and employees, and landlords and tenants;

(b) provide for all citizens, within the available resources of the country, facilities for work and adequate livelihood with reasonable rest and leisure;

(c) provide for all persons employed in the service of Pakistan or otherwise, social security by compulsory social insurance or other means.

(d) provide basic necessities of life, such as food, clothing, housing, education and medical relief, for all such citizens, irrespective of sex, caste, creed or race, as are permanently or temporarily unable to earn their livelihood on account of infirmity, sickness or unemployment;

(e) reduce disparity in the income and earnings of individuals, including persons in the various classes of the service of Pakistan; and

(f) eliminate riba as early as possible. 
Annexure-III

\section{Economic Coordination Committee (ECC) of the Cabinet}

\section{Composition}

1. The Prime Minister/Finance Minister Chairman

2. Minister for Commerce Member

3. Minister for Communications "

4. Minister for Food, Agriculture and Livestock ”

5. Minister for Industries, Production and Special Initiatives ”

6. Minister for Information Technology and " Telecommunications

7. Minister for Labor, Manpower and Overseas Pakistanis

8. Minister for Petroleum \& Natural Resources

9. Minister for Ports and Shipping

10. Minister for Privatization and Investment

11. Minister for Railways

12. Minister for Science and Technology

13. Minister for Textile Industry

14. Minister for Water \& Power

15. Adviser to the Prime Minister on Finance and Revenue

16. Minister of State for Commerce

17. Minister of State for Communications

18. Minister of State for Economic Affairs

19. Minister of State for Finance 
20. Minister of State for Industries, Production \& Special Initiatives

21. Deputy Chairman, Planning Commission

22. Governor, State Bank of Pakistan

23. Chairman, Securities \& Exchange Commission of Pakistan

\section{Special Invitation}

i) Chairman, Export Promotion Bureau.

ii) Chairman, Board of Investment.

iii) Secretary, Commerce Division.

iv) Secretary, Communications Division.

v) Secretary, Economic Affairs Division.

vi) Secretary, Finance Division.

vii) Secretary, Food, Agriculture \& Livestock Division.

viii) Secretary, Industries, Production and Special Initiatives Division.

ix) Secretary, Information Technology and Telecommunications.

x) Secretary, Petroleum \& Natural Resources Division.

xi) Secretary, Planning \& Development Division.

xii) Secretary, Railways Division.

xiii) Secretary, Revenue Division.

xiv) Secretary, Statistics Division.

xv) Secretary, Water and Power Division.

xvi) Secretary, Privatization Division.

xvii) Secretary, Board of Investment. 
xviii) Chief Economist, Planning Commission.

xix) Economic Adviser, Finance Division.

3. The Committee may invite such other officers to its meetings as may be required from time to time.

\section{Functions}

1. Consideration of all urgent economic matter and coordination of economic policies initiated by various Divisions of Government.

2. To identify and propose measures for the gradual attainment of a welfare state.

3. To keep a vigilance on the monetary and credit situation and make proposals for the regulation of credit in order to maximize production and exports and to prevent inflation.

4. To determine the future pattern of growth of major industries.

5. To review from time to time the country's import policy and its effect on production and Investment.

6. To evaluate export performance from time to time in relation to specific policies and measures for the promotion of exports.

7. To watch the current price situation with a view to ensuring the stability of the prices of goods used by the common man.

8. Implementation of any other task assigned by the Cabinet from time to time.

9. Cases of agreement and licensing for oil prospecting and exploration.

10. Six monthly/Annual reports on Autonomous Bodies.

11. Cases of non-repatriable foreign investment. .

12. Private sector schemes based on more than $50 \%$ imported raw material.

13. Cases involving fiscal anomalies.

14. Review of foreign aid utilization 


\section{Annexure-IV}

\section{Annual Plan Coordination Committee (APCC)}

\section{Functions}

1. To review Annual Plan of current year and to discuss and recommend Proposed Annual Plan of next year for submission to NEC.

2. To review Public Sector Development Program (PSDP) of current year and to recommend proposed PSDP of next year for submission to NEC.

\section{Composition}

1. Deputy Chairman, Planning Commission

Chairman

2. Governor, N.W.F.P., Peshawar

Member

3. Governor, State Bank of Pakistan

Member

4. Ministers for Finance and Planning \&. Development

Members of all provinces and $\mathrm{AJ} \& \mathrm{~K}$.

5. Deputy Chief Executive of Northern Areas Member

6. Chairman, P \& D Board, Punjab and Additional Chief Members Secretaries of Sindh, N.W.F.P, Balochistan and AJ\&. K.

7. Secretary, Planning \& Development, Northern Areas Member

8. Provincials' Finance Secretaries Members

9. Secretaries of all Federal Ministries/Chief Economist, Members Planning Commission.

10. Chairman, C.B.R/NHA/WAPDA/PAEC/PNRA/HEC/CDA Members

11. Economic Adviser, Finance Division/Additional Members Secretary (Budget), Finance Division/Director, PIDE. 


\section{Annexure-V}

\section{Priorities Committee}

\section{Functions}

1) To discuss and recommend the scheme-wise and overall allocations of Public Sector Development Program of next year for submission to APCC.

\section{Composition}

1. Additional Finance Secretary (Budget)

Chairman

2. Representatives of all Ministries/Divisions

Members

3. Technical Chiefs of P \& D Division

Members

4. Chief, Public Investment Programming Section

Member 


\section{Annexure-VI}

\section{Executive Committee of the National Economic Council (ECINEC)}

\section{Composition}

1. The Prime Minister/Finance Chairman

2. Minister for Commerce

Member

3. Minister for Communications

4. Minister for Education

5. Minister for Environment

6. Minister for Food, Agriculture and Livestock

7. Minister for Health

8. Minister for Housing \& Works

9. Minister for Industries, Production and Special Initiatives

10. Minister for Information Technology and Telecommunications

11. Minister for Local Government and Rural Development

12. Minister for Labor, Manpower and Overseas Pakistanis

13. Minister for Petroleum \& Natural Resources

14. Minister for Planning and Development (when appointed)

15. Minister for Ports and Shipping

16. Minister for Privatization and Investment

17. Minister for Railways

18. Minister for Science and Technology

19. Minister for Social Welfare $\&$. Special Education

20. Minister for Textile Industry 
21. Minister for Water \& Power

Member

22. Adviser to the Prime Minister on Finance and Revenue

23. Chairman, Higher Education Commission

24. Minister of State for Economic Affairs

25. Minister of State for Finance

24. Deputy Chairman, Planning Commission

\section{Provinces:}

1. Provincial Finance Ministers

2. Provincial Planning Ministers

3. Chairman Planning \& Development Board/Additional Chief Secretaries(Development) of the Provinces.

\section{Note:}

i) The Finance Minister, Planning Minister; and Additional Chief Secretary (Planning \& Development) of the Azad Govt. of the State of Jammu \& Kashmir will be specially invited in all the meetings of the Committee.

ii) Deputy Chief Executive and Chief Secretary, Northern Areas will also be specially invited in all meetings of the ECNEC.

\section{Functions}

i) Development Schemes costing more than Rs.500 million are submitted to ECNEC for its consideration/approval

ii) To allow moderate changes in the plan and sectoral re-adjustments within the over-all plan allocation.

iii) To supervise the implementation of the economic policies laid down by the Cabinet and the National Economic Council.

iv) Reports asked for by the Committee in pursuance of its earlier decisions. 
v) Any other matter referred to the Committee by the Prime Minister, the National Economic Council, the CCI or the Cabinet or raised by a member in the committee with the permission of the Chairman. 


\section{Annexure-VII}

\section{Scheme Appraisal and Approval Fora}

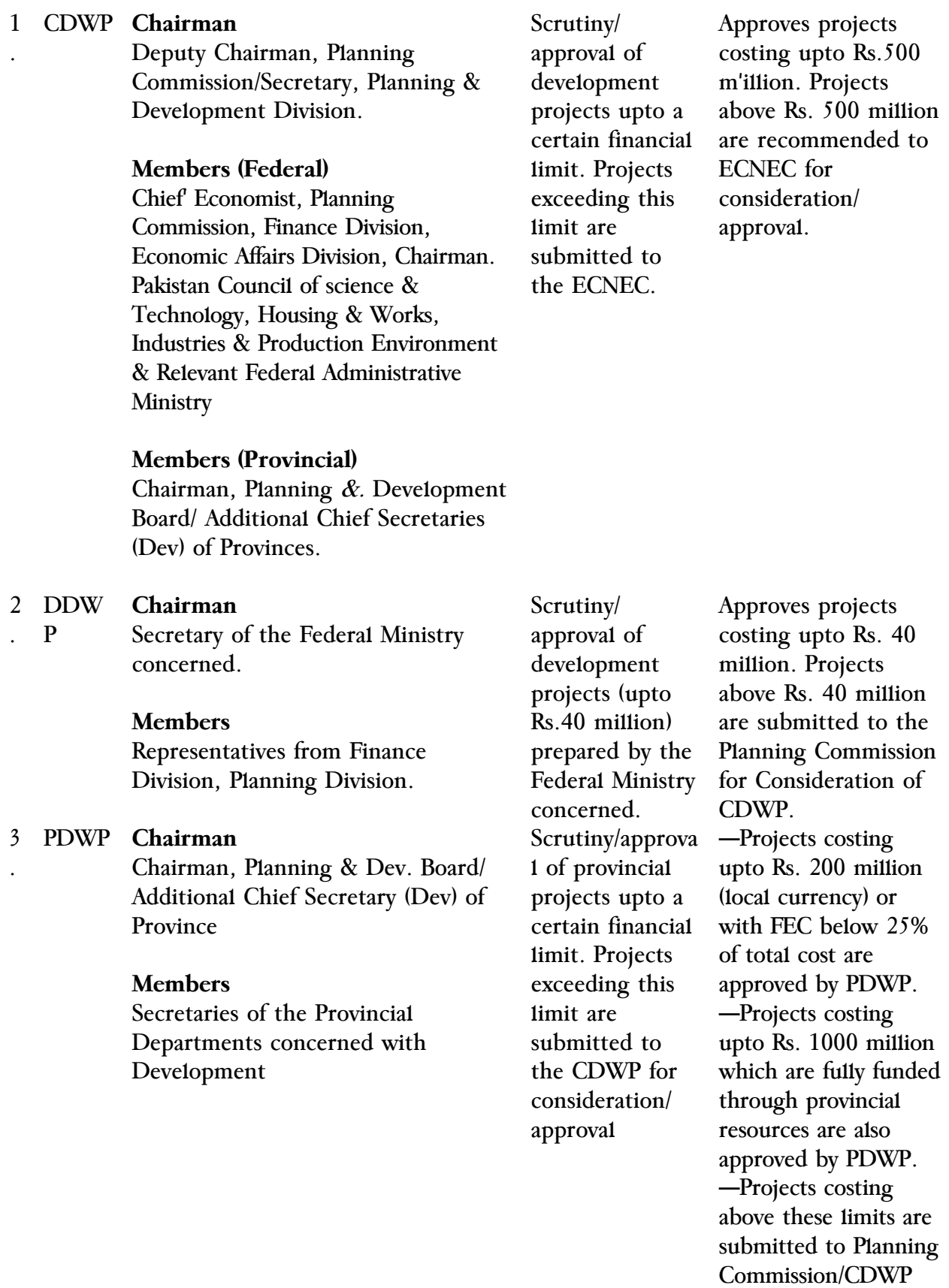




\section{Annexure-VIII}

\section{Monetary and Fiscal Policies Co-ordination Board}

\section{Composition}

(i) Federal Minister for Finance

(ii) Federal Minister for Commerce or Secretary Commerce Member

(iii) Deputy Chairman, Planning Commission

(iv) The Governor (SBP)

(v) Secretary, Finance Division, Government of Pakistan
Chairman

Member

Member

Member

\section{Functions}

(a) co-ordinate fiscal, monetary and exchange race policies;

(b) ensure consistency among macro-economic targets of growth, inflation and fiscal monetary and external accounts;

(c) meet for the purposes of clauses (a) and (b) before the finalization of the budget to determine the extent of Government borrowing from commercial banks taking into account credit requirements of the private sector, liquidity expansion determined by the Central Board and expected changes in net foreign assets of the banking system;

(d) meet on a quarterly basis to review the consistency of macroeconomic policies and to revise limits and targets set at the time of the formulation of the budget, keeping in view the latest developments in the economy;

(e) consider limits of government borrowing as revised from time to time in the meetings to be held before and after passage of the annual budget;

(f) review the level of Government borrowing in relation to the predetermined or revised targets after every quarter; and

(g) review the expenditure incurred in connection with raising of loans and Government borrowing. 
Annexure-LX

\section{Social Sector Coordination Committee (SSCC)}

\section{Composition}

1. Minister for Social Welfare and Special Education Chairperson

2. Minister for Culture, Sports and Youth Affairs Member

3. Minister for Education

4. Minister for Environment

5. Minister for Health

6. Minister for Housing and Works

7. Minister for KAN A

8. Minister for Labor, Manpower and Overseas Pakistanis

9. Minister for Law, Justice and Human Rights

10. Minister for Local Govt. and Rural Development

11. Minister for Population Welfare

12. Adviser to the Prime Minister on Finance

13. Adviser to the Prime Minister on Women Development

14. Deputy Chairman, Planning Commission

\section{Provinces}

15. Minister for Planning \&. Development, Punjab

16. Minister for Planning \& Development, Sindh

17. Minister for Planning \& Development, NWFP

18. Minister for Planning \&. Development, Balochistan 


\section{Annexure-X}

\section{Cabinet Committee on Investment (CCOI)}

\section{Composition}

i. The Prime Minister

Chairman

ii. Minister for Commerce

Member

iii. Minister for Communications

”

iv. Minister-for Food, Agriculture and Livestock

v. Minister for Industries, Production

vi. Minister for information Technology and Telecommunications

vii. Minister for Petroleum \& Natural Resources

viii. Minister for Privatization and Investment

ix. Minister for Textile Industry

x. Minister for Tourism

xi. Minister for Water \& Power

xii. Adviser for Finance and Revenue

xiii. Minister of State for Privatization and Investment

xiv. Deputy Chairman, Planning Commission

xv. Chairman, BOI

\section{Functions}

i) To consider investment proposals and projects involving relaxation in policies and incentives submitted by Board of Investment Secretariat.

ii) To accord approval to the investment proposals/projects in all sectors of the economy requiring consent and clearance of various Ministries 
and Divisions and resolve issues impeding realization of projects, their implementation and operation;

iii) To consider and approve the proposals/projects for development and management of industrial Zones, Free Trade Zones, Free Industrial Zones and Export Oriented Units;

iv) To deal with the issues facing existing industries/projects in operation and take decisions to resolve them;

v) To serve as a "clearing house" for resolving the issues relating to investment projects and authorize the office of the Board of investment to issue single permission so as to eliminate the need to seek redressal/permissions of various Ministries/Divisions/ Departments; and;

vi) To consider availability of utilities to be supplied by the concerned Departments while examining the investment proposals and give the investors firm indications of their availability or otherwise. On approval of the project, the line departments will be bound to supply the facility to the investors within thirty days on receipt of application from them. 


\section{Annexure-XI}

\section{Cabinet Committee on Privatization (CCOP)}

\section{Composition}

i) The Prime Minister

Chairman

ii) Minister for Commerce

Member

iii) Minister for Industries, Production and Special Initiatives

iv) Minister for-Information technology and Telecommunications

v) Minister for Labor, Manpower and Overseas Pakistanis

vi) Minister for Petroleum and Natural Resources

vii) Minister for Ports and Shipping

viii) Minister for Privatization and Investment

ix) Minister for Textile Industry

x) Minister for'Water and Power

xi) Adviser to the Prime Minister on Finance

xii) Deputy Chairman, Planning Commission

xiii) Governor, State Bank of Pakistan

xiv) Any other officer/persons, which the Privatization Commission may deem appropriate

Co-opted Member

\section{Functions}

i) To formulate the Privatization Policy for approval of the Government/Cabinet

ii) To approve the State Owned Enterprises to be privatized the recommendation of the Privatization Commission or otherwise. 
iii) To take policy decisions on inter-ministerial issues relating to the privatization process

iv) To review and monitor the progress of privatization.

v) To instruct the Privatization Commission to submit reports/information/ data relating to the privatization process or any other matter relating thereto.

vi) To take policy decisions on matters pertaining to privatization, restructuring, deregulation, regulatory bodies and Privatization Fund Account.

vii) To approve the reference Price in respect of the State Owned Enterprises being privatized.

viii) To approve successful bidders.

ix) To consider and approve the recommendations of the Privatization Commission on any matter.

x) To assign any other task relating to privatization to the Privatization Commission. 


\section{Annexure-XII}

\section{Cabinet Committee on Regulatory Bodies (CCRB)}

\section{Composition}

1. The Prime Minister

Chairman

2. Minister for Commerce

Member

3. Minister for Health

4. Minister for Industries, Production and Special Initiatives

5. Minister for Information \& Broadcasting

6. Minister for Information Technology and Telecom

7. Minister for Petroleum \& Natural Resources

8. Minister for Privatization and Investment

9. Minister for Water \& Power

10. Adviser to the Prime Minister on Finance and Revenue

\section{Functions}

i. To consider matters relating to the overall framework of Regulatory Bodies and their functioning.

ii. To consider issues connected to policy matters referred to the Committee by Regulatory Bodies or concerned Ministries/Divisions.

iii. To review the performance of Regulatory Bodies on a quarterly basis.

iv. To consider any matter referred to the Committee by the Prime Minister or by a Member of the Committee with the permission of the Chairman, or by the Cabinet. 


\section{Annexure-XIII}

\section{Cabinet Committee on Agriculture (CCA)}

\section{Composition}

1. The Prime Minister

Chairman

2. Minister for Commerce

Member

3. Minister for Food, Agriculture and Livestock

4. Minister for Industries, Production and Special Initiatives

5. Minister for Water \& Power

6. Adviser to the Prime Minister on Finance and Revenue

7. Governor, State Bank of Pakistan

8. Deputy Chairman, Planning Commission

Functions

i. To review agriculture policies as well as development plans in the sector and monitor implementation thereof.

ii. To review and monitor the progress of important projects and programs in the sector in order to ensure effective utilization and outcomes.

iii. To take decisions on inter-ministerial issues relating to the sector.

iv. To review proposals of agriculture pricing, agriculture inputs and credit as well as issues concerning annual crop production, marketing and exports.

v. To review the performance of major public sector organizations dealing with agriculture.

vi. To take up any matter referred to the Committee by the Prime Minister or by a Member of the Committee with the permission of the Chairman, or by the Cabinet. 


\section{Annexure-XIV}

\section{Planning and Development Division : Rules of Business}

I. (i) Preparation of Comprehensive National Plan for the economic and social development of the country;

(ii) Formulation, within the framework of the National Plan, of an annual plan and an annual development program; and

(iii) Recommendations concerning orderly adjustment therein in the light of new needs, better information and changing conditions.

2. Monitoring the implementation of all major development projects and programs; identification of bottlenecks and initiation of timely remedial action.

3. Evaluation of on-going and completed projects.

4. Review and evaluation of the progress achieved in the implementation of the National Plan.

5. Identification or regions, sectors and sub-sectors lacking adequate portfolio of projects and taking steps to stimulate preparation of sound projects in those areas.

6. Continuous evaluation of the economic situation and coordination of economic policies.

7. Organization of research in various sectors of the economy to improve the data base and information as well as to provide analytical studies which will help economic decision making

8. Association with the Economic Affairs Division in matters pertaining to external assistance in individual projects, from the stage prior to preliminary discussion up to the stage of final signing of documents with and giving agencies.

9. Development or appropriate cost and physical standards for effective technical and economic appraisal of projects. 
10. Coordination of all work pertaining to:-

(i) World Social summit

(ii) SAARC' (Human Resource Development)

(iii) International Poverty Alleviation Forums

11. National Logistics Cell.

12. Administrative control of

(i) Economists and Planners Group;

(ii) Pakistan Institute of Development Economics. 


\section{Annexure-XV}

\section{Finance Division : Rules of Business}

1. Finances of the Federal Government and financial matters affecting the country as a whole

2. The Annual Budget Statement and the Supplementary and Excess Budget Statements to he laid before the National Assembly, the schedules of authorized expenditure.

3. Accountants and Audit.

4. Allocation of share of each Provincial Government in the proceeds of divisible Federal Taxes; National Finance Commission

5. Public debt of the Federation both internal and external; borrowing money on the security of the Federal Consolidated Fund.

6. Loans and advances by (lie Federal Government.

7. Sanctions of internal and external expenditure requiring concurrence of (lie Finance Division.

8. Advice on economic and financial policies; promotion of economic research.

9. Proper utilization of the country's foreign exchange resources.

10. Currency, coinage and legal tender, Pakistan Security Printing Corporation and Pakistan Mint.

11. Banking, investment, financial and other corporations, that is to say:

- Central Banking; Stale Bank of Pakistan;

- Other banking (not including co-operative banking) and investment and financial corporations with objects and business not confined to one Province, and 
- Incorporation, regulation and winding up of corporations including banking insurance and financial corporations not confined to or controlled by or carrying on business in one Province.

12. Framing of rules of pay and allowances, retirement benefits, leave benefits and other financial terms and conditions of service.

13. Cost Accountancy.

14. Intentional Monetary Fund. 